\title{
SELECTED LEGAL ASPECTS OF TRANSACTION COSTS
}

\author{
Tomasz Famulski \\ Wydział Prawa i Administracji \\ Uniwersytet Jagielloński w Krakowie
}

\begin{abstract}
:
The aim of this article is to identify the relation between transaction costs and the law, both on theoretical and practical grounds. In literature various approaches on the issue of transaction costs are presented, but it was Ronald $\mathrm{H}$. Coase's discovery and explanation that turned out to be one of the most crucial determinants of the development of Law \& Economics. Thereby, the findings of economics on the issue of transaction costs are interfuses L\&E as a jurisprudential movement. Detailed analysis of selected current Polish legal regulations lead to a conclusion that some of those regulations generate transaction costs, while other limit the ability to transact. Concurrently, legal regulations that foster reduction of the level of transaction costs are indentified. In general conclusion it can be asserted that the previous assumption - legal regulations can affect transaction costs in both positive and negative way - is true.
\end{abstract}

Keywords: Law \& Economics, economic analysis of law, transaction costs, Ronald H. Coase.

JEL Class: D23, K00, K15, K20.

\section{INTRODUCTION}

In contemporary economics including finance, transaction costs are one of fundamental categories. The fact of incurring additional costs - apart from the price of purchased good or service which is the subject of a transaction - impossible to avoid has been noticed for centuries by many scholars. 
Nevertheless, transaction costs became the subject of insightful scientific research only in the second half of the $20^{\text {th }}$ century. Scientific concept of transaction costs was introduced by Ronald H. Coase, and his student Oliver E. Williamson who popularized and expanded the primary ideas. The importance of the issue of transaction costs and the research that follows them finds exemplification in both Coase and Williamson being awarded the Nobel Memorial Prize in Economics ${ }^{1}$. Coase was awarded precisely for „discovery and explanation of the meaning of transaction costs and property rights in institutional structures in economy" [Jasiński 2012: 128]. The value of Coase's achievement lays also in his inspiration for the jurisprudential movement of Law $\&$ Economics, because Coase referred to the role of legal regulations as an important factor influencing transaction costs ${ }^{2}$. This article concerns selected legal aspects relevant to the issue of transaction costs. This problem is not sufficiently recognized in the Polish literature, neither economic nor legal.

The purpose of the article is to identify relations between transactions costs and the law both on theoretical and practical grounds. In this context the first part of the paper is theoretical. It is an attempt at determining the influence of economics' approach on transaction cost on the development of relatively new jurisprudential movement of Law \& Economics. The second part of the article concerns practical issues. It tries to analyse and assess the influence of selected legal regulation on transaction costs connected with following phases of an economic exchange. The underlying assumption is that legal regulations can result in the rise of the level of transaction costs (negative effect), but they can also be means to reducing that level (positive effect). The study employs the method of literature research (which mostly comprises of foreign sources) and economic analysis of selected Polish legal regulations.

\section{ORIGINS AND DEVELOPMENT OF THE CONCEPT OF TRANSACTION COSTS}

The issue of impediments to exchange is probably present in economic reflection since its beginning. Some authors trace the issue as far back as Aristotle's time [Klaes 2008]. Indeed, the Stagirite reflected upon the advantages to exchange that come from the use of money. It was, however, much later that the scholars would see the impediments to exchange as an economic cost. Notable example

${ }^{1}$ Ronald H. Coase received the prize in 1991, Oliver E. Williamson - in 2009 [cf. Jasiński 2012: 128-130; 207-214].

${ }^{2}$ It should be noted, that influence on jurisprudence was not Coase's intention in The Problem of Social Cost, but rather pointing to the direction toward which the functional analysis of the economic system should be headed [Pomaskow 2016: 104]. 
comes from Carl Menger's theory of exchange. Menger realised that transactions require economic sacrifices, such as loss of time, transport costs, communication costs etc. However, he does not reflect upon them as opportunity costs [Menger 1871: 170-171]. By the end of the $19^{\text {th }}$ century a notion of costs of circulation was introduced. Such costs do not serve the creation of value, but are necessary for the circulation of capital. The term ,transaction costs" started to appear in financial markets in the 1930s, but would enter the economic literature for good at least post-war. The concept itself, though, is present in the movement of institutional economics, since this line of thought bases its economic thinking on transaction [Commons 1931: 648-657]. It is worth noting that the development of the concept reaches as far as having its own school of economic research, namely Transaction Cost Economics, introduced by Oliver Williamson [Williamson 1981: 548-577].

Transaction costs have been presented in the economic literature in various ways. There are three interpretations of the notion of transaction costs [Klaes $2008]^{3}$. The first can be called the narrow, monetary interpretation. In this interpretation it is assumed that the transaction costs are the direct costs that an economic agent incurs when engaging in a market transaction. The second interpretation is the relational interpretation. It is more broad in its spectrum than the monetary one, because it considers transaction costs as transcending beyond traditional dimensions of price and quantity. This interpretation played a pronounced role in Ronald Coase's theory of the firm and the economics of property rights. Such understanding of transaction costs is prevalent in Law \& Economics literature, and, therefore, it is assumed in this article. The third interpretation is the institutional one. It treats transaction costs as a part of analysis of economic institutions and tries to apply the concept of transaction costs to non-market settings.

From the point of view of this article to most important work on transaction costs are the writings of Ronald Coase. There are three articles written by Coase which are important for the concept of transaction costs ${ }^{4}$. In the first article, Nature of the Firm, Coase tries to answer the question why people do business rather than trade individually on a market. Coase reflects that market transactions often bear costs other than that of the purchased good or service. Forming firms is a way of reducing these costs [Coase 1937: 390-391]. This can been seen as an anticipation of the issue of transaction costs. The second article, The Federal Communications Commission, concerns the distribution of radio broadcasting frequencies in the United States from 1910 to 1959. In those days,

${ }^{3}$ Douglas W. Allen proposes only two interpretations: a property rights approach and neoclassical approach [cf. Allen 2000: 895-904].

${ }^{4}$ Though Coase himself would start addressing them in this way only in the 1970s. In his earlier work he used expressions such as 'marketing costs' or 'costs of market transactions'. 
the frequencies were assigned by public administration. Coase argues that if there were well-formulated property rights attached to the frequencies, state intervention would not be necessary, because the frequencies would become effectively allocated through market transactions [Coase 1959: 25]. This is an important observation in view of transaction costs, namely that well-formulated property rights make the transactions easier. It follows that they contribute to economically effective resource allocation. The third and last article, The Problem of Social Cost, reflects upon the issue of externalities. In Coase's view, externality could be a subject of transaction, if the transaction costs were zero. Due to transaction costs, economically effective allocation is hindered. Furthermore, if the transaction costs were zero, legal regulations would not matter, because efficiency would result in any case. However, such situations do not appear in reality, so it is advisable that law should lead to allocation such as if there were no transaction costs [Coase 1960: 27-28]. The aforementioned observations would later became the basis of what is nowadays called the Coase Theorem (although Coase himself did not formulate said theorem explicitly).

\section{DEFINITION OF TRANSACTION COSTS}

The transaction cost can be defined as a cost incurred in making an economic exchange. Robert Cooter and Thomas Ulen distinguish three steps of an economic exchange. Each of these steps is related to the transaction costs.

The first step is finding another party willing to make an economic exchange, namely a partner willing to buy the offered good or offering a good desired by the searching party. Transaction costs related to this first step can therefore be called search costs. The subject of the transaction plays an important part here. If the good or service in question is rare, it will be more difficult - and therefore costly - to locate suitable exchange partner. However, if the subject of the transaction is common and easily accessible, the search costs will be low [Cooter and Ulen 2012: 88].

The second step distinguished by Robert Cooter and Thomas Ulen is bargaining. In this step of an economic exchange, as Cooter and Ulen suggest, the amount of information relevant to the transaction obtained by the parties plays a vital part. Transactions concerning basic goods or basic services do not require high bargaining transaction costs, due to the fact that information necessary to make such transactions is public. In this case „public” means the information is known to all parties practically at the start of bargaining. For example, a transaction which subject is a loaf of bread is not costly in the sense of transaction costs, because the commodity is known to the customer, the price 
is sufficiently low not to be a case for negotiation, and any doubt about customer's solvency will end at the cash register. Significantly higher transaction costs occur when the exchange takes place in a situation where only one party has the information relevant to the transaction, in other words when the relevant information is private. For the transaction to be made, this information has to become public, that is it has to be released to the other party or parties. However, trading partners might not be willing to reveal at least some of their knowledge. It follows that the process of revealing information may be costly, especially at the expense of the time spent negotiating. An example of such a transaction is buying a used car. The buyer wants to know as much he or she can about the vehicle. The seller is not willing to reveal information that might negatively affect the perception of the car offered. Furthermore, the seller wants to know how much the buyer can afford, or in other words, desires information about the financing of the transaction on the buyer's side.

The number of parties involved in the exchange is important during the bargaining stage, and so are the communication problems between those parties. A larger number of parties will generate larger transaction costs. Communication problems may arise not only from the need to travel to a distant place of exchange, nuisances related to setting a date suitable for all of the parties, but also from negative attitude of the parties, their irrational behaviour, or cultural differences.

The culmination of the bargaining phase often means formulating an agreement between the parties. Determining the content of an agreement may also cause transaction costs to arise. The more specific are the contract, the higher are the costs. The parties may desire to include provisions concerning various contingencies in the agreement. Coming to mutual understanding about these provisions might prove time-consuming. Costly legal services often must be taken under consideration.

The third and last step of an exchange is fulfilment of the agreement. The agreement might need to be enforced, hence the name of the kind of transaction costs related to said step - enforcement costs. If the fulfilment takes place in a short period of time, principally it does not generate enforcement costs. However, if the fulfilment is a long process, policing it may turn out to be costly. This includes not only supervision of the trade partner's performance, but also execution of contractual penalties and a need for further clarification of contract provisions which might occur during enforcement phase, especially in the presence of unforeseen circumstances.

It can be inferred from this distinction that each phase of an exchange has its own transaction costs. The level of these costs is determined by various factors. The characteristics of a transaction that are relevant to transaction costs can be classified into two groups: factors that foster lower transaction costs and factors 
that contribute to higher transaction costs [Cooter and Ulen 2012: 91]. The first group consists of such characteristic as standardized good or service, clear, simple rights, few parties, friendly parties, familiar parties, reasonable behavior, instantaneous exchange, no contingencies, low costs of monitoring, cheap punishments. The latter consists of unique good or service, uncertain, complex rights, many parties, hostile parties, unfamiliar parties, unreasonable behavior, delayed exchange, numerous contingencies, high costs of monitoring, costly punishments.

The enumeration above states that clarity of rights (or lack thereof) is an important factor for the issue of transaction costs. It is not difficult to notice that law can affect the level of transaction costs either directly or in an indirect way. Law and transaction costs are often intertwined, and observation of this relation constitutes one of the foundations of a scientific movement called Law \& Economics ${ }^{5}$. It is also worth noting that Williamson considered his Transaction Cost Economics to be interdisciplinary endeavor, comprising of economics, organization theory and selected aspects of the law (especially contract law) [Williamson 2010: 13].

\section{TRANSACTION COSTS AND LAW \& ECONOMICS}

Coase's ideas, especially those presented in The Problem of Social Cost turned out to be inspiring for the legal academia and became a classic of what is now known as the Law \& Economics movement. This movement can be defined as application of economical methods to legal analysis. Proponents of $L \& E$ analyse law - rules, institutions, their creation, structure, related processes and their effect on reality - in an economical fashion [Kornhauser 2015]. The existence of a relationship between law and economy is obvious. Development of many branches of the law, e. g. private law, commercial law, corporate law is basically an answer to the development of economic relations. Conversely, the economic situation of a country is largely influenced by the structure of financial law or labour law. Even the country's economic system may be sanctioned by law. Functioning of a legal system is inevitably connected with existence of various public institutions. Their presence is, of course, economically relevant. What makes Law \& Economics exceptional among other schools of legal thought is the fact that the methods of economics are applied consequently to all of the branches of law. It follows that even the branches which are, at least at first sight,

${ }^{5}$ The movement is sometimes called „economic analysis of law” (term often used in Polish literature on the subject), from the title of one of the pioneering books by Richard A. Posner, first released in 1973. The book had many editions, the latest being [Posner 2014]). 
economically irrelevant or relevant only in a very indirect way are economically analysed, e. g. criminal law or constitutional law. Proponents of L\&E research the law as a factor affecting economic reality. From this point of view, legal regulations are not something fixed outside of an economic system, but rather they constitute choices which results affect the economy [Mackaay 2000: 65].

Law \& Economics is both descriptive and normative in its character. Representatives of this school do not only research and describe law in economic categories, but also propose new legal regulations which they deem economically efficient. This dual approach is reflected by the efficiency thesis proposed by Richard A. Posner, which says that the law, especially American common law, both is and should be economically efficient ${ }^{6}$.

There are several key concepts which lay at the foundation of Law \& Economics which, when applied to law, constitute its economic analysis. These are the rational choice theory and closely related utility maximization thesis, efficiency of law, bargaining theory [Stelmach et al. 2007: 30-34], and the Coase Theorem, which is supported by the concept of transaction costs. The importance of the issue of transaction costs for law cannot be overstated, and is perhaps best reflected by the title of an entry in the The New Palgrave Dictionary of Economics and the Law, namely 'lawyers as transaction cost engineers' [Gilson 1998].

\section{EXAMPLES OF POLISH LEGAL REGULATIONS AFFECTING TRANSACTION COSTS}

Generally speaking, there a two possible relations between law and transaction costs. Law can either provoke transaction costs to arise or it can help to reduce them $^{7}$. Making a complete list of legal regulations affecting transaction costs would require one to analyze and assess every single legal rule, task not only dreary, but practically impossible given the amount of effective acts of law. What is worth noting, however, is the fact that law can affect transaction costs in every phase of an exchange, that is the search and information phase, bargaining phase, and the policing and enforcement phase ${ }^{8}$. On a side note, from a legal point of view a transaction almost always takes a form of contract, as it is reflected in the following examples. It has been pointed out, however, that transaction costs can occur also in non-market exchanges [Klaes 2008], and it is possible that law influences such situations as well, but this subject is out of

${ }^{6}$ In newer editions of Economic Analysis of Law Posner presents different and perhaps weaker versions of the thesis, but remains its staunch defender.

${ }^{7}$ Of course some legal regulations do not affect transaction costs in any way.

8 This distinction of three transaction steps, although sometimes with slightly different wording (but the same meaning), is widely popular in transaction costs literature. 
the scope of this analysis. The examples presented are mostly based on Polish legal regulations, and are ordered in correspondence to the aforementioned phases of transaction.

The search and information phase concerns finding a suitable exchange partner. It does not merely consist of realizing that another party exists. The party should at least to some degree seem trustworthy, and verifying the trustworthiness might prove to be costly. Analogical point could be made about the subject of the transaction. There are several examples of legal regulations that may help to reduce transaction costs in this phase. For example, the existence of National Court Registry (Krajowy Rejestr Sadowy) which provides detailed information about various economic entities'. Among the businesses included in the National Court Registry are general partnerships, limited liability companies, joint-stock companies, limited partnerships, limited liability partnerships, partnerships limited by shares, and cooperatives. The Registry also lists various foundations, societies, trade unions and similar entities. It also contains a list of insolvent debtors. Information disclosed in the Registry pertains entity's name, address, addresses of its branches, partners, in some cases the marital status of its partners and, possibly, contract of matrimonial property rights, entity's capital. It also states who is authorized to act for the entity and clarifies if the firm is in tax debt, under execution of a court judgement, and if its operation has been suspended, among other, even more detailed information. Similar registries exist in other countries, e.g. Companies House in the United Kingdom. Another example of a legal institution helpful in the search and information phase is land registration (ksiega wieczysta) ${ }^{10}$. It provides information pertaining the legal status of properties. The information is legally presumed to be true, and the institution strengthens the certainty of property status, in contrast to movables. The existence of land registration eases the supposed transactions.

In the bargaining phase the parties negotiate the provisions of the contract. Law's role in this phase may often be negative, but it is not always the case. Civil law consist of three kinds of rules: imperative, semiimperative and dispositive [Morawski 2008: 56-57]. The imperative rules cannot be limited or excluded by the parties, they unequivocally require them to fulfill certain obligations. Obviously, this limits the scope of possible provisions to a contract and generates transaction costs. For example, Article 158 of the Polish Civil Code [Ustawa z dnia 23 kwietnia 1964 r. - Kodeks cywilny, DzU 1964, nr 16, poz. 93 z późn. zm.] requires a notarial deed for a legally valid transfer of

${ }^{9}$ Regulated by Ustawa z dnia 20 sierpnia 1997 r. o Krajowym Rejestrze Sądowym, DzU 2016, poz. 687, 996.

${ }^{10}$ Regulated by Ustawa z dnia 6 lipca 1982 r. o księgach wieczystych i hipotece, DzU 2016, poz. $790,996,1159,1948$. 
a property. The civil law is of course not the only branch of law containing imperative rules. A lot of requirements are set by administrative law. For instance, its subbranch, antitrust law, goes as far as requiring a permission from and administrative body for a merger or an acquisition (in Poland - Chairman of the Office of Competition and Consumer Protection, by order of Article 18 of Polish Protection of Competition and Consumers Law [Ustawa z dnia 16 lutego 2007 r. o ochronie konkurencji i konsumentów, DzU 2007, nr 50, poz. 331 z późn. zm.]). It is worth noting that complicated law will result in a need to hire legal assistance by the parties, especially in complex transactions, like a corporate acquisition, thus raising transaction costs. However, the lawyers are actually hired as a mean to lower transaction costs resulting from legal regulations - it would be much harder for the parties to come to a legally valid agreement on their own [Gilson 1998: 512-513].

The semiimperative rules also set certain unavoidable obligations, but they do leave some room for negotiation. Rules of this kind are meant to protect the weaker party, e. g. a consumer in a transaction with a firm or an employee signing a contract with an employer. The semiimperative rules set a minimal standard for a provision, however it can be changed as long as it is in the interest of the weaker party. An example of such rule is Article 23 Section 4 of Polish Protection of Tenants' Rights Act [Ustawa z dnia 21 czerwca 2001 r. o ochronie praw lokatorów, mieszkaniowym zasobie gminy i o zmianie Kodeksu cywilnego, DzU 2001, nr 71, poz. 733 z późn. zm.], which states that the rent for a social housing flat cannot be higher than the half of the lowest rent in the commune's housing resource.

The dispositive rules are quite different than the imperative and semiimperative rules, because they do not have to be necessarily followed by the parties. They provide regulation of a certain matter only if the parties did not settle the matter differently or the parties did not mention a relevant provision in the contract at all. From the point of view of transaction costs dispositive rules play a positive role, because their existence can significantly shorten the time needed to negotiate the contract - it would be hard for the parties to agree upon provisions for every possible contingency. Dispositive rules also do not limit the scope of the possible provisions of a contract. An example of such rule is Article $668 \S 1$ of the Polish Civil Code which states that the tenant has the right to sublet the property if the contract does not state otherwise. It is worth noting that the positive aspect of the dispositive rules is shared by at least some of the imperative rules, namely when they regulate certain issues that the parties would probably not even consider to settle differently, such as the interpretation of the expression ,middle of the month" (which, as the Polish Civil Code states, means the fifteenth day of the month). They also provide regulation for various contingencies, thus saving time during negotiation, however their drawback lies 
in the fact that regardless of the circumstances those regulations are always definite.

The third phase of a transaction, the policing and enforcement phase, can generate transaction costs only when the fulfillment of the contract is spread over time. Transaction costs related to this phase are high when the party has to be supervised, violations of the contract are hard to notice and the punishment is expensive to administer. Legal regulations may play positive part under certain circumstances. For instance, the parties may disagree on the understanding of certain terms used in the contract. Law may provide some guidelines in such situation. For example, Article 65 of the Polish Civil Code clarifies how declarations of will ought to be understood, and states that mutual agreement expressed in a contract should take precedent over the literal meaning of the words used in it. Also, unforeseen circumstances might occur, making the aforementioned the imperative and dispositive rules come into action. Were it not the case, the parties would probably have to renegotiate the contract, which would seem much harder in such situation, and would certainly be expensive in terms of transaction costs. Finally, a dispute between the parties might occur on the subject whether the contract actually has been violated. Such dispute will often find its end only in a court of law, in this case exemplified not by a single legal rule, but rather by the whole Civil Procedure Code [Ustawa $\mathrm{z}$ dnia 17 listopada 1964 r. Kodeks postępowania cywilnego, DzU 2016, poz. 1822, $1823,1860,1948]$ itself. Without it the transaction under dispute might never be fulfilled, and parties would be left helpless.

\section{CONCLUSION}

Relations between law and economics have been a subject of scientific interest since long ago. The presence of these issues has been noted in philosophical and political writings for centuries [Beldowski and Metelska-Szaniawska 2007: 52]. It was not until the second half of the $20^{\text {th }}$ century, however, that the scientific research movement of Law \& Economics has been developed. Considerations of this article indicate that one of the most crucial determinants of the development of Law \& Economics is the discovery and explanation of the meaning of the transaction costs by Coase.

Economic literature provides many takes on the issue of transaction costs and defines them in various ways. From the point of view of the relations between law and transaction costs Coase's theory should be considered as the basic one, due to the fact that it was Coase who pointed out that only in the situation of zero transaction costs the law is irrelevant, because the exchange partners will be able to achieve efficient allocation of resources by means of 
transaction. In reality, transaction costs are always present. They are incurred by the partners during the search for a suitable party, but also during later phases of transaction, namely bargaining and enforcement. One of the important factors affecting the transaction costs in each of these phases are legal regulations. The expression 'lawyers as transaction costs engineers' explicitly reflects the meaning of legal regulations for the issue. Theoretical inquiry enables one to formulate a general constatation about a sui generis symbiosis of law and economics on the ground of transaction costs. Analysis of selected Polish legal regulations, including commercial and civil law (its imperative, semiimperative and dispositive rules) leads to a certain practical conclusion. On one hand, some legal regulations generate transaction costs, other limit the ability to transact. On the other hand, there are examples of legal regulations that foster the reduction of the transaction costs. Thereby, the assumption that law can affect the level of transaction costs in both positive and negative ways ought to be considered true.

\section{REFERENCES}

Allen D. W., 2000, Transaction costs, [w:] B. Bouckaert, G. De Geest (red.), Encyclopedia of Law and Economics. Vol. I. The history and methodology of Law and Economics, Edward Elgar, Cheltenham.

Bełdowski J., Metelska-Szaniawska K., 2007, Law \& Economics - geneza i charakterystyka ekonomicznej analizy prawa, „Bank i Kredyt”, nr 10.

Coase R., 1937, The nature of the firm, „Economica”, no. 4.

Coase R., 1959, The Federal Communications Commission, „The Journal of Law \& Economics” no. 2.

Coase R., 1960, The problem of social cost, „The Journal of Law \& Economics”, no. 3.

Commons J. R., 1931, Institutional economics, „American Economic Review”, vol. 21.

Cooter R., Ulen T., 2012, Law \& Economics, Addison-Wesley.

Gilson R. J., 1998, Lawyers as transaction cost engineers, [w:] P. Newman (red.), The New Palgrave Dictionary of Economics and the Law, Palgrave Macmillan.

Jasiński L. J., 2012, Nobel z ekonomii 1969-2011. Pogląy laureatów w zarysie, Instytut Nauk Ekonomicznych Polskiej Akademii Nauk, Key Text, Warszawa.

Klaes M., 2008, Transaction costs, history of, [w:] S. N. Durlauf, L. E. Blume (red.), The New Palgrave Dictionary of Economics, Second Edition, Palgrave Macmillan.

Kornhauser L., 2015, The economic analysis of law, [w:] E. N. Zalta (red.), Stanford encyclopedia of philosophy.

Mackaay E., 2000, History of Law and Economics, [w:] B. Bouckaert, G. De Geest (red.), Encyclopedia of Law and Economics. Vol. I. The history and methodology of Law and Economics, Edward Elgar, Cheltenham.

Menger C., 1871, Grundsätze der Volkswirtschaftslehre, Braumüller, Wien.

Morawski L., 2008, Wstęp do prawoznawstwa, Dom Organizatora, Torun.

Pomaskow J., 2016, Twierdzenie Coase'a a narodziny ekonomicznej analizy prawa, „Studia Ekonomiczne. Zeszyty Naukowe Uniwersytetu Ekonomicznego w Katowicach”, nr 259. 
Posner R. A., 2014, Economic analysis of law, Wolters Kluwer Law \& Business, New York.

Stelmach J., Brożek B., Załuski W., 2007, Dziesięć wyktadów o ekonomii prawa, Wolters Kluwer, Warszawa.

Ustawa z dnia 16 lutego 2007 r. o ochronie konkurencji i konsumentów, DzU 2007, nr 50, poz. $331 \mathrm{z}$ późn. zm.

Ustawa z dnia 17 listopada 1964 r. Kodeks postępowania cywilnego, DzU 2016, poz. 1822, 1823, $1860,1948$.

Ustawa z dnia 20 sierpnia 1997 r. o Krajowym Rejestrze Sądowym, DzU 2016, poz. 687, 996.

Ustawa z dnia 21 czerwca 2001 r. o ochronie praw lokatorów, mieszkaniowym zasobie gminy i o zmianie Kodeksu cywilnego, DzU 2001, nr 71, poz. 733 z późn. zm.

Ustawa z dnia 23 kwietnia 1964 r. - Kodeks cywilny, DzU 1964, nr 16, poz. 93 z późn. zm.

Ustawa z dnia 6 lipca 1982 r. o księgach wieczystych i hipotece, DzU 2016, poz. 790, 996, 1159, 1948.

Williamson O. E., 1981, The economics of organization: The transaction cost approach, „The American Journal of Sociology”, vol. 87(3).

Williamson O. E., 2010, Transaction cost economics: An overview, [w:] P. G. Klein, M. E. Sykuta, The Elgar Companion to Transaction Cost Economics, Edward Elgar, Cheltenham -Northampton.

\section{WYBRANE ASPEKTY PRAWNE KOSZTÓW TRANSAKCYJNYCH}

\section{Streszczenie:}

Celem niniejszego artykułu jest identyfikacja relacji pomiędzy kosztami transakcyjnymi a prawem, tak w płaszczyźnie teoretycznej, jak i praktycznej. W literaturze przedmiotu zagadnienie kosztów transakcyjnych znajduje różne ujęcia, jednak to odkrycie i wyjaśnienie znaczenia kosztów transakcyjnych przez Coase'a okazało się jedną z najbardziej kluczowych determinant rozwoju Law \& Economics. Tym samym dorobek nauk ekonomicznych w zakresie kosztów transakcyjnych przenika się z L\&E jako nurtem nauk prawnych. Szczegółowe analizy wybranych przepisów obowiązującego polskiego prawa prowadzą do wniosku, że niektóre z regulacji prawnych generują koszty transakcyjne, inne zaś ograniczają możliwość dokonywania transakcji. Jednocześnie zidentyfikowane zostały przepisy, które sprzyjają zmniejszaniu kosztów transakcyjnych. W uogólnionej konkluzji można zatem uznać za prawdziwe przyjęte założenie o możliwości oddziaływania tak pozytywnego, jak i negatywnego przepisów prawa na wielkość kosztów transakcyjnych.

Słowa kluczowe: Law \& Economics, ekonomiczna analiza prawa, koszty transakcyjne, Ronald H. Coase. 